\title{
A bor veleje, a család ereje! A hazai borászatok társadalmi és környezeti felelősségi gyakorlatáról
}

\section{Essence of Wine - Strength of Family: Hungarian wine makers' social and environmental responsibility practice}

\author{
Vajdovich, Nóra *
}

\section{* Budapesti Gazdasági Egyetem / Budapest Business School. nora.vajdovich.10@unibge.hu}

Abstract: In the current socio-economic climate, major corporations are increasingly obliged to make efforts to contribute to the community and the environment. This research seeks to answer the question of what motivates a family business to fulfil ethical expectations of CSR. In the study, moral, strategic, and personal motivations are considered, along with the possible motive of remaining competitive. In order to interpret the findings the study relies on stakeholder theory, the theory of socio-emotional wealth, and the theoretical framework of responsible ownership. The study covers two dimensions of CSR: the issues of social and environmental responsibility.

Keywords: corporate responsibility; social responsibility; family business; wine sector

Absztrakt: Társadalmunkban végbemenő állandó gazdasági, társadalmi és környezeti változások miatt egyre több vállalat kénytelen komoly erőfeszítéseket tenni a közösségért és a környezetért. Kutatásunkkal arra kerestük a választ, hogy mi motiválhat egy családi vállalkozást a vállalati társadalmi felelősségvállalással összefüggő etikai elvárások betartására. Erkölcsi, stratégiai és/vagy személyes indíttatásból, esetleg a versenyképesség megőrzése érdekében tesz-e különféle erőfeszítéseket a vállalkozás a környezetért és a közösségért? Családi vállalkozások esetében magyarázatul szolgálhat a stakeholderelmélet és a szocioemocionális vagyon elmélete, emellett szintén releváns a felelős tulajdonlás elméleti keretrendszere is. Tanulmányunkban a vállalati társadalmi felelősségvállalás két dimenzióját, a társadalmi és környezeti felelősségvállalás kérdéskörét járjuk körbe.

Kulcsszavak: társadalmi felelősségvállalás; környezeti felelősségvállalás; családi vállalkozás; borászati szektor

Citation

Vajdovich, N. (2021). A bor veleje, a család ereje! A hazai borászatok társadalmi és környezeti felelősségi gyakorlatáról. Prosperitas, 8(2), 2. Budapest Business School.

https://doi.org/10.31570/prosp_2021 _0002

History:

Received:

Last Revised:

Accepted:

Published:
7 Jun 2021

16 Sept 2021

28 Sept 2021

4 Nov 2021

\section{Bevezetés}

A vállalati társadalmi felelősségvállalás témájában számtalan tanulmány jelent meg az elmúlt években, azonban kifejezetten a családi vállalkozások CSR-tevékenységével foglalkozó már jóval kevesebb annak ellenére, hogy a családi vállalkozások a világ gazdaságának kiemelkedően fontos szereplői (Sharma et al., 1996). A publikációk a legkülönbözőbb nézőpontokból vizsgálják a vállalati társadalmi felelősségvállalás és a családi vállalkozások kapcsolatát. A publikációk egy része a családi és nem családi vállalkozások CSR-tevékenységét hasonlítja össze (Craig \& Dibrell, 2006), más tanulmányok a családi vállalkozások kedvező kimenetelű CSR-tevékenységét, az imázs javitása és a hírnév megtartása miatti etikus viselkedését hangsúlyozza (Dyer \& Whetten, 2006). Több kutató szerint viszont a családi vállalkozásokra kevésbé jellemző a felelős gondolkodás, mert kizárólag a saját érdekeiket tartják szem előtt (Morck \& Yeung, 2003).

A felelős társadalmi és környezeti gondolkodás és viselkedés mindig is a hazai családi vállalkozások sajátja volt, bár az ezzel összefüggő tevékenységeket korábban nem neveztékvállalati társadalmi felelősségvállalásnak. Ezek a tevékenységek a családi vállalkozások természetéből fakadnak, melyek kapcsán a nem pénzügyi szempontok (Gomez-Mejia et al., 
2007) és a hosszú távú orientáció kiemelt jelentőségűek. A vállalati társadalmi felelősségvállalás kis- és középvállalkozások, különösen a családi tulajdonban lévő vállalkozások esetében ritkán valósul meg intézményes keretek között. A vállalati társadalmi felelősségvállaláshoz kapcsolódó intézkedésekre szánt pénzügyi eszközök a tulajdonos család szándékától és érzelmeitől függenek. Tekintettel arra, hogy a családtagok és alkalmazottak ugyanazokat az értékeket és meggyőződéseket vallják a nem pénzügyi célok fontosságát tekintve, és mindenki ismeri a nem pénzügyi célok fontosságát, nincs is szükség a vállalati társadalmi felelősségvállalás intézményesítésére (Fernandó \& Almeida, 2012). Az ügyfelekkel és alkalmazottakkal való korrekt viselkedés, a természeti erőforrások racionális kihasználása és a helyi közösségekkel ápolt korrekt viszony a vállalkozás saját céljait is szolgálja. Ezeket a célokat bizonyos mértékben a CSR-tevékenységek révén érik el.

Az egész világon növekvő tendenciát mutató borfogyasztás miatt egyre fontosabbá válik a környezeti fenntarthatóság javítására irányuló felelősség is (Marshall et al., 2010). Egyre több borászat működik egyre környezettudatosabban fenntartható borok készítésével. A borfogyasztók is egyre tudatosabbá válnak a borok minőségével kapcsolatban. Az előállítás környezeti hatásaira vonatkozó tájékoztatás és a különböző környezetvédelmi tanúsítások megléte befolyásolhatja vásárlási döntésüket és borpreferenciájukat is (Alonso, 2010). Silverman és Lanphar (2003) a boripar által okozott legjelentősebb környezeti károk között említette az energia- és vízfogyasztást, a szennyvíztermelést, a felhasznált vegyszereket és a csomagolóanyagok használatát. A borászatoknak ennek megfelelően a vízfogyasztás közösségre gyakorolt hatásaival és a hulladékgazdálkodással kapcsolatos problémákat kell kiemelten kezelniük.

Tanulmányunkban arra törekszünk, hogy bemutassuk a borászatok fenntarthatósági kezdeményezéseit, mi motiválhatja a családi vállalkozásokat felelős társadalmi és környezeti gondolkodásra és viselkedésre. Tanulmányunkhoz olyan szőlő- és bortermelő családi vállalkozásokat választottunk ki, amelyek mindkét területen jó példával járnak elöl.

Kutatásunk elsősorban a családi vállalkozás vállalati társadalmi és környezeti felelősségvállalásával kapcsolatos céljaira és motivációjára összpontosít. A következő kutatási kérdésekre kerestük a válaszokat:(1) melyek a családi vállalkozások társadalmi és környezeti felelősségvállalással kapcsolatos céljai? (2) melyek a családi vállalkozások társadalmi és környezeti felelősségvállalással kapcsolatos motivációi? (3) a társadalmi és környezeti felelősségvállalás miként érhető tetten a vállalkozások egyes működési területein? valamint (4) a fenntarthatósággal kapcsolatos tevékenység milyen módon befolyásolja az érintettekkel való viszonyt?

Tanulmányunk első részében bemutatjuk a családi vállalkozások vállalati társadalmi felelősségvállalásával foglalkozó szakirodalomban felvázolt elméleti keretet, ezt követően ismertetjük a kutatási módszertanunkat, elemzésünket, majd ismertetjük az eredményeinket.

\section{Elméleti háttér}

\subsection{A családi vállalati társadalmi felelősségvállalás meghatározása}

A vállalati társadalmi felelősségvállalásnak nincs egységes meghatározása a fogalomban rejlő sokszínűség és multidimenzionalitás miatt. Tanulmányunkban a vállalati felelősségvállalást a vállalkozás társadalom javításához való hozzájárulásának tekintjük (Etzioni, 1996), olyan megközelítésnek, amelynek célja az egyéni szabadság és a közösség, társadalom közötti egyensúly megteremtése (Etzioni, 1993).

Napjainkra elfogadottá vált, hogy a CSR-tevékenységek vállalati működésbe történő beépítése gazdasági előnyöket - értékesítés és piaci részesedés növelése, márka erősödése, a dolgozói motiváció növelése, a vállalati imázs erősödése és a működéssel kapcsolatos költségek csökkenése - hozhat a vállalat vagy vállalkozás számára (Bank, 2017).

A magyar szerzők meghatározásai közül Szlávik (2009) a következőképpen foglalja össze a vállalati társadalmi felelősségvállalás lényegét: „A vállalatok társadalmi felelősségvállalásában az a vállalati gyakorlat, amikor a vállalat értékrendje és célrendszere alapján önkéntes, a szabályozáson túlmutató módon környezeti és társadalmi szempontokat épít be az érintettekkel való kapcsolatrendszerébe és működési gyakorlatába" (Szlávik, 2009, p. 54).

A környezettel foglalkozó tudományterületek kutatóinak körében elterjedt az a nézet, hogy a vállalatokat elsősorban az intézményi, illetve a társadalmi nyomás ösztönzi 
környezetbarát müködésre és tevékenységekre. A családi vállalkozások tulajdonosait valószínüleg egészen más motivációk is vezérlik, nevezetesen a szocioemocionális vagyon megtartása, mely fogalom részletezésre kerül. Felmérései szerint a családi vállalkozások jobb környezeti teljesítményt nyújtanak - különösen helyi szinten -, mint a nem családi tulajdonú vállalatok, mert így védik szocioemocionális vagyonukat. A beágyazottságukból adódó társadalmi, érzelmi nyomás általában környezettudatos cselekvésekre készteti őket, amelyek természetesen hatással vannak a helyi környezetre. Egyrészt a családi vállalkozások tulajdonosai sokkal kiszolgáltatottabbaknak számítanak a külső érintettek esetleges negatív értékelései miatt, másrészt a pénzügyi szempontoktól függetlenül a saját érdekükben nagyobb értéket tulajdonítanak a környezettudatos magatartásnak. A gyengébb környezeti teljesítmény a család hírnevének csorbulásához, szégyenkezéshez és a szocioemocionális vagyon elvesztéséhez vezetne, még akkor is, ha az gazdaságilag kockázatos. Ugyanilyen fontos érv lehet a családi vállalkozások környezettudatos viselkedése mellett a hosszú távú jövőképük (Aragón-Correa \& Sharma, 2003), vagyis azok a vállalattulajdonosok, akiknek az üzlet hosszú távú fenntartása fontos, hajlamosabbak a leszármazottak javát szolgáló döntéseket hozni.

\subsection{A szocioemocionális vagyon kapcsolata a családi cégek fenntarthatósági törekvéseivel}

A családi vállalkozásokról szóló szakirodalomban kifejtett, a CSR-tevékenységekkel kapcsolatos nézetek igencsak eltérőek. Sok szerző amellett érvelt, hogy a családi vállalkozások szociálisan érzékenyebbek, hiszen igyekeznek hírnevüket, nem gazdasági preferenciájukat és szocioemocionális vagyonukat megőrizni (Cennamo et al., 2012). A nem etikus „családiasság", a nem családtagokkal szembeni bizalmatlanság és a család minden más elé helyezése azonban negatívan befolyásolhatja a társadalmi felelősségvállalást.

A szocioemocionális vagyon elmélete szerint a cégek úgy hozzák meg döntéseiket, hogy közben szem előtt tartják referenciapontjukat, alapvetéseiket vagy az úgynevezett szocioemocionális vagyonukat. A családi vállalkozások nagyobb valószínűséggel vesznek részt a társadalmi felelősségvállalásban még akkor is, ha ez nem jár számukra gazdasági előnyökkel, mert ezért érzelmi, vagyis szocioemocionális jutalomban részesülnek (Berrone et al., 2012).

Gomez-Mejia (2011) a szocioemocionális vagyon fogalmának tágabb jelentést tulajdonított. Az általa megadott meghatározás magában foglalja a családtagok hatalomgyakorlását, a családi befolyást, a céggel való azonosulást, valamint a családot (az egyéneket) és a vállalatot összekötő, mélyen gyökerező, belső pszichológiai kötődést. A szocioemocionális vagyon alapvetően a döntési mechanizmust befolyásolja, így pozitív és negatív hatása is lehet a vállalkozás teljesítményére (Habbershon \& Williams, 1999).

A szocioemocionális vagyon keretrendszere magyarázattal szolgálhat a családi vállalkozások nem racionális logikára épülő társadalmi felelősségvállalására is.

A szocioemocionális vagyon mérésére Berrone és munkatársai (2012) egy öt dimenzióból álló rendszert dolgoztak ki, amely az úgynevezett FIBER-skála néven vált ismertté a családi vállalkozást kutatók körében, melynek elemei a következők: családi ellenőrzés és befolyás; családtagok céggel való azonosulása; szociális kötelékek; családtagok érzelmi kötődése; valamint a családi kötelékek dinasztikus öröklés révén történő megújitása.

A fenntarthatósággal összefüggésben kiemelendő a családtagok céggel való azonosulása, a szociális kötelékek szerepe, valamint a családi kötelékek dinasztikus öröklés révén történő megújitása. A FIBER-skála második dimenziója arra mutat rá, hogy a család azonosítja magát a vállalattal. Számos kutató jutott arra a megállapításra, hogy a vállalat és a család összefonódása adja a családi vállalatok egyediségét. A tulajdonló család identitása elválaszthatatlan a vállalattól, így a vállalat sokszor a család „kiterjesztésének” tűnik (Bingham et al., 2011). A családi cégek így várhatóan hajlandóak támogatni minden olyan társadalmi gyakorlatot, amely javítja az imázsukat és legitimitásukat a környezetük szemében. Ugyanakkor a személyes ismertségük vagy esetleges felelőtlen szociális viselkedésük miatt veszteség érheti őket a szocioemocionális vagyonukat tekintve (Berrone et al., 2010). A családi vállalkozások előszeretettel használják a vállalati társadalmi felelősségvállalást a család és vállalkozás érzelmi szükségleteinek kielégítésére, például az imázs és hírnév fenntartása és növelése érdekében (Dyer \& Whetten, 2006).

A szociális kötelék kifejezés mögött a családi vállalkozások társadalmi kapcsolatai húzódnak meg. A szocioemocionális vagyon olyan kapcsolatokat biztosithat, amelyek kollektív előnyökben - például bizalom, szolidaritás, szoros kapcsolati tőke stb. - nyilvánulnak meg. A 
kölcsönös kötődések nemcsak a családtagokra jellemzőek, de más jellegű kapcsolatok széles körére is kiterjedhetnek (például beszállítók). A családi vállalkozások gyakran mélyen beágyazódnak a helyi közösségbe - például támogatóként vagy segítőként - jótékonyságból, nem pedig anyagi haszonszerzés céljából. A szocioemocionális vagyon védelmének egyik módjaként a családi vállalkozások érzékenyebben reagálnak a külső érintettek (környezet, közösség, ügyfeleik) igényeire, mint a nem családi vállalkozások.

A családi kötelékek dinasztikus öröklés révén történő megújitása dimenzió a vállalat következő generációra hagyásának szándékát jelenti. Zellweger és Astrachan (2008) a transzgenerációs fenntarthatóságot tartotta a szocioemocionális vagyon központi elemének. Kutatások bizonyítják, hogy a következő generációnak való továbbadás szándéka a családi vállalkozások egyik legfontosabb célja (Zellweger \& Kellermanns, 2011).

\subsection{A stakeholder-elmélet a családi vállalkozások sajátos múködési rendszerében}

A stakeholderelmélet szerint a vállalat különböző érdekelt egyénekkel vagy csoportokkal áll kapcsolatban, vagyis a vállalatok nem önmagukban, mindentől függetlenül, hanem egy sokszínű kapcsolatokkal átszőtt társadalmi környezetben működnek. A vállalat felelősséggel tartozik azokért, akik befolyással vannak a cselekedeteire.

Az eredetileg Freeman (1994) által leírt stakeholderelmélet lényege az érintettek érdekeinek figyelembevétele, miszerint a vállalat érintettjei hozzájárulhatnak a vállalat sikeréhez. Az elmélet alapján az érintettek nemcsak a nyereségen keresztül kapcsolódhatnak a vállalathoz, de összhangba tudják hozni egymással a gazdasági és nem gazdasági szempontokat is.

Spence (2014) arra a megállapításra jutott, hogy a kis- és közepes vállalkozások valószínűleg nagyobb hangsúlyt fektetnek a családra és az érintettekre a személyes kapcsolatok fontossága miatt. A család, mint érintett mellett a tulajdonos menedzserek is erősen támaszkodnak saját alkalmazottaikra, akik persze lehetnek családtagok, és akikkel szoros kapcsolatot ápolnak (Uhlaner et al., 2004).

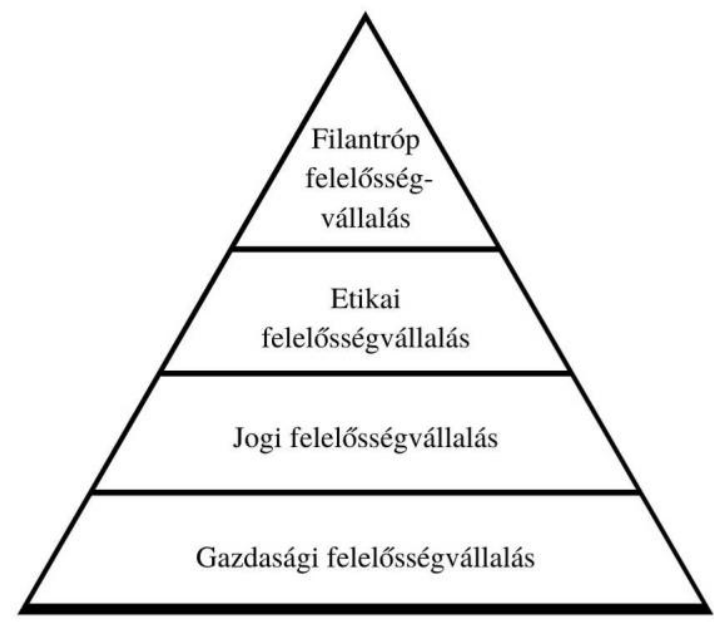

1. ábra. A társadalmi felelősségvállalás piramisa. Forrás: Carroll, 1979

Carroll (1979) eredetileg a nagyvállalati környezetre megfogalmazott elmélete szerint négy alkotóelem együttes megléte szükséges a vállalati társadalmi felelősségvállalás megvalósításához kisvállalkozások esetében is (lásd: 1. ábra). Carroll (1979) a gazdasági felelősséget tekinti alapnak, hiszen erre tud csak ráépülni a jogi, majd az erkölcsi/etikai felelősség, a piramis csúcsán pedig a filantróp magatartás szerepel, amely az önként vállalt, az életminőség javítását célzó, belső motivációból fakadó felelős viselkedést jelenti. 


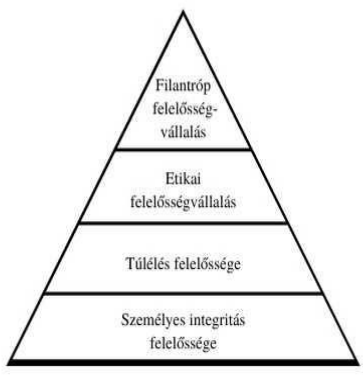

a) Felelósség önmaga és a család felé

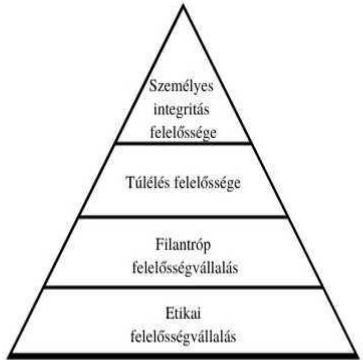

c) Felelôssség a helyi közösség felé

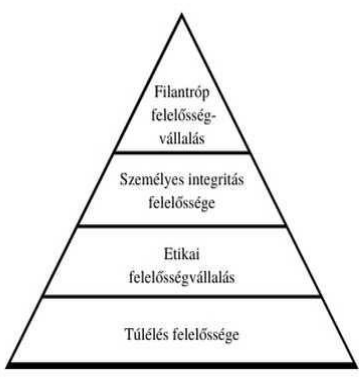

b) Felelősség az alkalmazottak felé

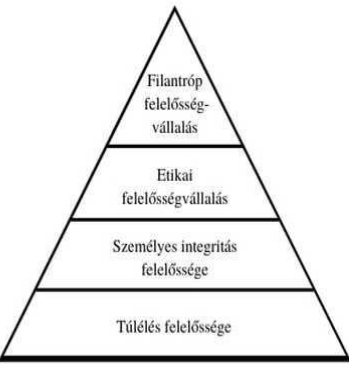

d) Felelősség az üzleti partnerek felé

\section{2. ábra. Kisvállalkozások társadalmi felelősségvállalása. Forrás: Spence, 2014}

Spence (2014) kisvállalkozásokra (lásd: SBSR vagyis Small Business Social Responsibility) átdolgozott modelljében (lásd: 2. ábra) a piramis könnyen átlátható építőelemei lehetővé teszik a CSR-területek fontossági sorrendjének megállapítását. Az alkotóelemek fontossági sorrendje eltérhet, az a tulajdonos vezető felelősségén és döntésein múlik. A piramisok alján a felelős viselkedés kiindulópontja található, a piramis tetején pedig a kívánatos, de nem elengedhetetlen szempontok.

- Önmagával és a családdal szembeni felelősség: egyrészt a vállalkozás túlélése alapvető követelmény, a személyes kötődés, különösen az alapító kötődése, a gazdasági és jogi státusz elvesztésének lehetősége és a megélhetés biztositásának felelőssége;

- Az alkalmazottakkal szembeni felelősség: A munkakörnyezet közvetlenségéből adódóan a legtöbb kisvállalkozás esetében az alkalmazottak rendkívül fontosak a szervezet működése szempontjából;

- A helyi közösséggel szembeni felelősségvállalás;

- Az üzleti partnerekkel (beszállítók, vásárlók stb.) szembeni felelősségvállalás.

A Spence (2014) által kisvállalkozások CSR tevékenységére módosított, négy piramisból álló modell jó adoptálható a kis családi vállalkozásokra, hiszen megjelennek benne a családhoz kapcsolódó jellegzetességek is.

A családi vállalkozások esetében is fontos kiemelni a vállalkozások - szintén a stakeholderelméleten alapuló - etikus megközelítését is, amelynek fontos szempontja, hogy a vállalatnak nemcsak az érintettjeit kell beazonosítania, de tisztában kell lennie azok szempontrendszereivel is, és ideális esetben figyelembe is kell vennie azokat (Bank, 2017).

\subsection{A felelös tulajdonlás elmélete}

A családi vállalkozások CSR-tevékenységének magyarázatul szolgálhat a felelős tulajdonlás (responsible ownership) elmélete is. Az eredetileg nagyvállalatokra vonatkozóan kidolgozott fogalom Lambrect és Uhlaner (2005) nevéhez füződik. Aminoff (2004) a felelős tulajdonlást egy pozícióként, egy szerepként, egy kockázatokkal, kötelezettségekkel és aggodalmakkal együtt járó feladatként határozta meg. A felelős tulajdonlás egyensúlyt teremt a tulajdonjogokkal járó kiváltságok (mint például hatalom, motivációs és örömforrások, jólét) és a tulajdonlással együtt járó feladatok, kockázatok között. 
A felelős tulajdonlás lényege, hogy a vállalatok hozzájárulnak a társadalmi fejlődéshez is azontúl, hogy termékeket és szolgáltatásokat nyújtanak (Besser, 1998). A társadalmi felelősségvállalás tehát a vállalat külső és belső érintettjeivel szembeni felelősséget foglalja magában. E magatartásért a tulajdonosok felelnek, de az nagyobb vállalkozások esetében sokszor annyira széttagolt, hogy ők már nehezen tudnak befolyást gyakorolni a döntéshozó menedzsmentre (Maher \& Andersson, 2002). Abban az esetben, ha a vállalkozás, mint tulajdon egy család kezében összpontosul, a tulajdonosoknak lehetőségük van a vállalat társadalmi felelősségvállalását is meghatározni, etikai kérdésekben is dönteni. Így a vállalati társadalmi felelősségvállalás a tulajdonosoktól függ, a végső felelősség pedig a menedzsmentre hárul (Amonarriz \& Landart, 2016).

Amonarriz és Landart (2016) kibővítette a fogalmat a felelős családi tulajdonlás koncepciójára. A szerzők meghatározása szerint ez maga után vonja a tulajdonosoknak a család és az érintettek iránti hosszú távú elköteleződését, a felelős magatartást, továbbá egyensúlyba kerülnek a családi tulajdonjogokkal járó kiváltságok és jogok a kötelezettségekkel és kockázatokkal.

\section{Módszertan}

\subsection{Adatgyưjités, mintaválasztás}

A primer jellegű kutatásunk során közvetlenül, elsődleges vizsgálatok révén - félig strukturált interjúk segítségével - gyűjtöttünk információkat a borászattal foglalkozó családi vállalkozások szereplőiről. Megfigyelhettük viselkedésüket, megismerhettük az ágazat jelentős vállalkozóinak a fenntarthatósági törekvésekkel kapcsolatos véleményét és motivációit.

Kutatásunk lefolytatásához a kvalitatív módszertant választottuk, mert ez a keretrendszer illeszkedik legjobban kutatási céljainkhoz. Adatainkat személyes megkérdezéssel kívántuk összegyűjteni, mert célunk a megértés volt, így a vizsgált téma ezzel a módszerrel volt a legalaposabban feltárható és megérthető.

Kutatásunkhoz nem állt rendelkezésre családi borászatokkal kapcsolatos adatbázis, így nem a véletlenszerü mintavételi eljárást alkalmaztuk (Babbie, 2017). Az interjúalanyokat a saját magunk által, ismeretség útján felépített adatbázis alapján választottuk ki. Olyan családi vállalkozókat kerestünk meg, akiknek a vállalkozása családi vállalkozásként határozza meg magát, és a borászati szektorban müködik. Sem a cég méretét, sem a vállalkozásban dolgozó generációk száma nem szerepelt bekerülési feltételként.

A családi vállalkozások meghatározására a Budapesti Gazdasági Egyetem Budapest LAB Vállalkozásfejlesztési Központjának 2019-ben megfogalmazott definícióját (Kása, Radácsi, \& Csákné, 2019) használtuk. E meghatározás családi vállalkozásnak tekinti azokat a vállalkozásokat, amelyek (1) önmagukat családi vállalkozásnak tartják, vagy (2) ahol a cég legalább ötven százaléka legalább egy család tulajdonában van, vagy (3) a család részt vesz a vállalkozás irányításában, vagy (4) a családtagok alkalmazottként vesznek részt a vállalat müködésében, vagy (5) a vezetés és a tulajdonlás átadása részben vagy teljes egészében a családon belül valósul meg.

Kutatásunkat a kutatási kérdések megfogalmazásával kezdtük, majd az adatgyűjtés és az adatfelvétel következett. Az interjúk hangfelvételeiről átiratok készültek, végül az így kapott adatokat az NVivo 12 szoftver segítségével strukturáltuk. Első lépésben a szakirodalom alapján az elsődleges kódokat határoztuk meg. A kódolást a kutatási kérdéseinknek megfelelően végeztük. Az első kutatási kérdésünk megválaszolásához a Basco (2017) modellnek megfelelően azonosítottuk a családi és vállalkozási nem gazdasági célokat. A második kutatási kérdésünk megválaszolásához a FIBER skála öt pontját, valamint a Spence (2014) által meghatározott érintett csoportokat használtuk elsődleges kódoknak. A harmadik és negyedik kutatási kérdések esetében szintén a Spence féle csoportokból alakítottuk ki a főkódokat. A kódokat alkódokba integráltuk, összesítettük az illeszkedő és átfedésben lévő témákat, majd kialakítottunk a végső csoportosítást.

Tanulmányunk alapját öt interjú adja. Nem tekintjük tanulmányunk feladatának sem az általánosíthatóságot, sem a reprezentativitást (Denzin \& Lincoln, 2011). Célunk az ágazaton belüli családi vállalkozások gyakorlatainak bemutatása, illetve a figyelem felhívása a téma fontosságára. 


\subsection{A vizsgált minta, a megkérdezett családi vállalkozások bemutatása}

Az Ungerbauer Családi Pincészet és Szőlőiskola a Csongrádi borvidék kiemelkedő borászata. A Tisza közelében, homoktalajon fekvő családi gazdaságban három generáció dolgozik együtt. Gazdaságukban 1986 óta foglalkoznak szőlőtermesztéssel és borászattal. Az Ungerbauer-szőlőiskola a gyökeres szőlő-szaporítóanyag legnagyobb eloállitója az országban, és az Alföld legnagyobb és legrégebben üzemelő telepe. Ungerbauer György 2010-ben nyerte el, eddig egyetlen szőlész-borászként, az Év Vállalkozója díjat, ugyanebben az évben a Csongrád Megye Év Borásza címmel is kitüntették. Lánya, Ungerbauer Anikó a vállalkozás vezetője és stratégiájának megalkotója, a borászat és az ahhoz tartozó egyéb tevékenységek első számú menedzsere. Szívügyének tekinti környezete hagyományainak tiszteletét és ápolását. Családi borászatuk mottójában is a szőlő szeretetét és a termőföld tiszteletét emelik ki.

A Pécsinger Szőlőbirtok a Pannonhalmi-Sokoróaljai borvidék mára legnagyobb és legmodernebb szőlészete. A Pécsingerek családi birtokát Pécsinger János és fia, ifjabb Pécsinger János irányítja. Igazi családi borászat, ahol a család több generációra visszatekintő múlttal és tapasztalattal irányítja a gazdaságot. A családi vállalkozásban együttműködnek a generációk, mindenkinek megvan a maga feladata. A folyamatos technológiai fejlesztések és a sokéves tapasztalat ötvözése olvasható ki a Pécsinger család birtokának jelmondatából: „A bor veleje, a család ereje!” Céljuk a „gondosan művelt szőlőből kiváló bort, unokáinknak pedig jövőt" teremteni, Pécsinger János szavaival élve.

A Takler Pincészet hazánk, azon belül a szekszárdi borvidék egyik legmeghatározóbb családi borbirtoka. A Takler család az 1770-as évek óta foglalkozik borászattal. Felelevenítve a hagyományt és tudást, a család 1987 óta családi vállalkozásként működik. A család három férfi tagja, Takler Ferenc és két fia, ifjabb Ferenc és András családi összefogásban müködteti a vállalkozást. Takler Ferenc a 2004-es év bortermelője, borász, az ő feladata a szőlészeti és pincemunkák irányítása. A Borkonferencia által kiválasztott ötven legjobb magyar borász között 2020-ban Takler Ferenc is helyet kapott.

Az 1991-ben alakult Pendits Szőlőbirtok és Pincészet Tokaj-Hegyalján müködik családi vállalkozásként. Az édesanya ügyvezetőként látja el az adminisztratív feladatokat, továbbá ő felel a szőlőmunkák beosztásáért és a stratégiáért. A legidősebb fiuk szintén a cég tulajdonosa, és a cég borászati részét vezeti, beleértve a palackozást és a címkézést is. A másik két fiú, akik külföldön élnek, a szüretre jönnek haza segíteni, emellett nemzetközi borbemutatókon és szakvásárokon gyakran képviselik a családi borászatot.

1. táblázat: Minta bemutatása. Forrás: saját munka

\begin{tabular}{ccccc}
\hline Borászat & Borvidék & Alapító & Borász & Termōterület mérete \\
\hline $\begin{array}{c}\text { Ungerbauer Családi Pincészet } \\
\text { és Szőlőiskola }\end{array}$ & Csongrádi & Aktív & Családtag & 21-60 Ha \\
Pécsinger Szőlőbirtok & Pannonhalmi & Aktív & Családtag & $21-60 \mathrm{Ha}$ \\
Takler Pincészet & Szekszárdi & Aktív & Családtag & $61-120 \mathrm{Ha}$ \\
$\begin{array}{c}\text { Pendits Szőlőbirtok és Pincé- } \\
\text { szet }\end{array}$ & Tokaji & Aktív & Családtag & $<20 \mathrm{Ha}$ \\
Hunyady Pincészet & Dél-Balatoni & Aktív & Családtag & $<20 \mathrm{Ha}$ \\
\hline
\end{tabular}

A Pendits családi borászat Magyarországon elsőként kapta meg a Rudolf Steiner munkásságán alapuló minősítést, a Demeter International szervezet Demeter védjegyét a környezettudatos magatartás szigorú elöírásainak követéséert. A biodinamikus borászat nem egy vallási irányzat vagy pillanatnyi fellángolás, hanem egy holisztikus gondolkodásmód, életfilozófia és életforma, amely tiszteletben tartja az ökológiai egyensúlyt, törekszik a borvidék jellegzetességeinek megőrzésére, valamint igyekszik megóvni a természet és az ember kapcsolatát.

Hunyady József gróf és felesége, Almásy Katalin grófnő a rendszerváltás után költözött haza Somogyba, és telepedett le őseik birtokán, akik közül Hunyady József gróf (1863-1942) a Dél-Balaton legnagyobb szőlőbirtokosa volt. A Hunyady grófok az 1700-as évek óta foglalkoznak szőlőtermesztéssel és borkészítéssel. Hunyady József gróf Svájcban született, és 
Olaszországban nevelkedett, anyai ágon a híres toszkán főnemesi, szőlő- és bortermelő Incisa della Rochetta családból származik. „A Hunyady-szőlőbirtokot „integrált módszerrel« művelik, csak az Európai Unió agrár- és környezetvédelmi programjában engedélyezett vegyszereket, és azokat is csak a lehető legkisebb mennyiségben használva. Vegyszeres gyomirtó szert nem használnak.

Az interjúalany borászatok áttekintő adatai az alábbi táblázatban kerültek összefoglalásra (1. táblázat).

\section{Elemzés}

Az interjúk elemzésénél a Spence-féle (2014) négyes felosztást követjük, kiegészítve a természeti környezet felé történő és a filantróp felelősséghez kapcsolódó felelős viselkedés bemutatásával. A környezeti felelősségvállaláshoz kapcsolódó részben az interjúk értelmezése kapcsán a felelős viselkedéshez kapcsolódó motivációkat elemezzük.

\section{(1) Felelősség a család és önmaga felé}

A Spence (2014) által kidolgozott piramis első dimenziója a vállalkozás önmagával és a családdal szembeni felelőssége. A vezető személyes integritása, saját magával szembeni elvárása és kiszámíthatóság nélkül nem lehet a vállalkozásért, másokért felelősséget vállalni. A vezető személyének feddhetetlensége, megbízhatósága mindenekelőtt való, fontos a család, a környezet, az alkalmazottak, a beszállítók és a versenytársak előtt is.

A személyes imázs után következik a vállalkozás gazdasági értelemben történő életben tartásához, túléléséhez kötődő felelősség. Az interjúkban a család megélhetésének biztosítása és a vállalkozás gazdasági sikeressége a két legfontosabb célként jelent meg. „A vállalat biztonsága nagyon fontos, anélkül ez nem megy. Egyébként a családi, illetve a család és a vállalkozás közötti harmónia kardinális kérdés" (Pécsinger János).

Az alapító szerepe különösen nagy hangsúlyt kap a CSR-tevékenységekben is. Az alapító és a tulajdonos család értékrendje alapjaiban véve határozza meg a tevékenységeket. „A saját filozófiánkat és életérzésünket osztjuk meg másokkal. A családom egy jelentős része, ahogy a nagypapám is, iskolaigazgató, a nagymamám is pedagógus volt. Alapvetően ennek a családnak mindig is volt valamilyen szintű beágyazottsága a társadalom szövetébe. Az elődök iránti tisztelet és a név kötelez" (Pécsinger János).

Az alapító/vezető értékeit a saját kultúrája (Hofstede, 2011) és belső motivációi is befolyásolják. „A nagyapám már az ötvenes években csinált a birtoka egy nagy részén egy madárrezervátumot. Ez volt az első magánrezervátum Olaszországban. És utána..I az olasz WWF elnöke lett, az édesanyám is az első tagok egyike lett. A nagyanyám is, az édesapám is mindig nagy természetvédő volt Olaszországban. Igen, ez az egész a családból jött" (Hunyady József).

(2) Az alkalmazottakért való felelösség

A belső érintetti kör második, általunk vizsgált csoportja az alkalmazottak köre. A tulajdonosok részéről erős felelősségtudat figyelhető meg, amely sokszor anyagi (hosszú távú szerződések, kiszámítható jutalmak, szolgálati lakás biztositása) és lelki segítségben is megmutatkozik. A munkavállalók megbecsülésének további jele a különleges alkalomra adott ajándék (például egy karton bor húsvétkor és karácsonykor).

A vezető (sokszor az alapító) személyes jelenléte és példamutatása a munkavállalók lojalitását erősíti.

Szintén megfigyelhető volt a tulajdonosoknak az alkalmazottak jóllétéhez való felelősségteljes hozzáállása, hiszen a vállalkozás sikeres működése a munkavállalók megélhetésének biztosítéka. A vállalkozások túlélése különösen fontossá vált a pandémiás időszakban, amikor maguknak a munkaadóknak a megélhetése is veszélybe került, ennek ellenére a bevétel nélküli időszakban is felelősséget vállaltak a munkavállalóikért. A vendéglátásban dolgozó kollégáknak a szőlőben igyekeztek munkát adni (például metszés vagy egyéb könnyebben megtanulható tevékenység), így fenntartva a munkaviszonyt és biztosítva az alkalmazottak családjának megélhetését.

A vállalati kultúra és a munkavállalók megbecsülésének része a részükre kialakított családias, de a vállalkozáshoz méltó, színvonalas és biztonságos munkakörnyezet és a 
munkavállalók képzésének finanszírozása, amely szintén kölcsönös előnyökkel jár mind a vállalkozás, mind a munkavállalók részére.

Megfigyelhető volt, hogy a hosszú távú stratégiai döntések szempontjából fontos a hosszú távon alkalmazott munkavállaló, illetve cél olyan alkalmazottak kiválasztása, akik a családnak fontos értékekkel összhangban, hosszú távon gondolkodnak a munkájukat illetően. „Itt, Somogyban mindig nehéz volt megfelelő munkaerőt találni. Mindig külföldről vagy meszszebbről kellett hozni őket, és azt is biztosítani kellett valamilyen módon, hogy itt is maradjanak. Az, hogy jól érezzék itt magukat, itt maradjanak nálunk dolgozni, és folytassák a gazdálkodást, a birtokos érdeke is volt" (Hunyady József).

Az eltérő szociális helyzetű munkaerő (roma származásúak, kismamák) munkába való bevonása és a diverzitás etikus kezelése kapcsán a tulajdonosok magatartása példaértékű a bemutatott borászatok esetében.

A méltányos és igazságos bánásmód különösen fontos a családi vállalkozások számára. „próbálunk jól bánni velük, mert most már régóta nálunk dolgoznak. szerintem elégedettek. Ez kint a földeken is fontos, mindig kedvesnek kell lenni meg jól kell bánni az alkalmazottakkal, és meg kell próbálni megtartani őket, bármi történjék" (Hunyady József).

\section{(3) A helyi közösségért való felelősség}

Spence (2014) piramisának harmadik dimenziójának alsó fokán a helyi környezettel szembeni etikai felelősségvállalás áll; idetartoznak a pontos kifizetések, de a jó minőségü termékek is.

Astrachan (1988) rámutatott arra, hogy a családi vállalkozás és a helyi közösség, amelyben működik, szoros kapcsolatban áll egymással. A vállalkozás családi jellege hatással van a helyi környezettel való kapcsolatára.

A család és a cégvezető személyes kapcsolatai szorosabbá tehetik a helyi közösséggel kialakított viszonyt. Ez azon családok számára, amelyeknek a vállalkozása és/vagy a terméke a család nevét viseli, különösen fontos, hiszen a család hírnevét teszik kockára. „jó érzés, hogy ismert a nevünk, és mindenképpen fenn kell tartani a jó hírnevet a mögöttünk álló nagy hagyomány miatt" (Hunyady József).

A környezettel való összhang előtérbe helyezése a cég hosszú távú sikeréhez és kiegyensúlyozott működéséhez vezet (Astrachan, 1988). Az együttműködésre való készség elismerést vív ki, és a család jó hírnevét öregbíti. „Legutóbb hozzánk került tizenkét hektár szőlő. Bejött a bácsi és ezt mondta: »János, ide figyelj, én már nem tudom csinálni, a lányom nem akarja..., a kisunokám pedig még csak nyolcéves. Örizzétek még tíz évig ezt a szőlőt, és majd adjátok oda neki úgy, amilyen állapotban most van. Úgyhogy addig őrizzük, amíg a gyerek nagykorú nem lesz, és majd ő eldönti, hogy csinálja vagy nem csinálja. Nem fogja csinálni, az biztos, hétszentség, mert ha nem nevelik bele, akkor nem fogja csinálni” (Pécsinger János).

Ha a családi vállalkozások alaposan ismerik a környezetük által kínált erőforrásokat, azokat felhasználhatják társadalmi és gazdasági fejlődésükhöz is. A helyi környezetbe való integráció és a közösséggel való együttműködés befolyással van az üzleti döntésekre. A helyi környezet alatt azonban nemcsak a vállalkozás székhelyét érthetjük, de idetartoznak a vállalkozás által működtetett boltok, értékesítő- és vendéglátóhelyek stb. hálózata is. Ebben a tekintetben is igyekeznek figyelembe venni a helyi beszállítók érdekeit.

Az alapító személyes motivációja a helyi közösség érdekében végzett munkában is tetten érhető. „megalapítottam egy egyesületet 2016-ban, a Bokrosi Hagyományőrző Egyesületet. Építettünk egy játszóteret 2019-ben, amely jelenleg az Alföld legjobban felszerelt, minőségi játszótere automata öntözőrendszerrel, közterületen... Fákat, virágokat ültettünk, rózsákat, növényeket" (Ungerbauer Anikó).

A helyi közösség iránti elköteleződés sok esetben a természeti környezetre is kiterjed. „Ha például telepítünk erdőt, akkor már inkább őshonos fákat ültetünk, amelyek bár lassabban nőnek, mint a tölgyek, de legalább nem akác, amely nem őshonos, meg a természetnek is árt" (Hunyady József).

\section{(4) Felelősség az üzleti partnerek felé}

a, Beszállitók

Amikor válaszadóinkat a beszállítókról kérdeztük, főként a velük kialakított régóta tartó kapcsolatról beszéltek, elkötelezettségüket hangsúlyozták. Többen említették, hogy a szállítókkal több évtizedes kapcsolatot ápolnak. Ezek a beszállítok gyakran a helyi közösségből kerülnek ki, karbantartásokat végeznek, esetleg olyan családokról van szó, akiktől a szőlőt 
vásárolták fel. Ha van rá lehetőség, mindig inkább helyieket választanak. „nagyon fontos, hogy vannak olyan szőlőtermelők, akikkel már tizenöt-húsz éve együtt dolgozunk” (Takler András).

Ritkán cserélik le a beszállítókat, ha probléma adódik, inkább megpróbálják orvosolni. Sokszor személyes barátság alakul ki a beszállítókkal, amely túlmutat egy egyszerü üzleti kapcsolaton. A személyes kapcsolatoknak és a beosztottakkal való bizalmi viszonynak köszönhetően az alkalmazottak nagyobb önállósággal rendelkeznek a beszállítókkal való kapcsolattartás terén is.

A beszállítói kapcsolatok közé sorolható a bérlői viszony is, amelyben az anyagi érdek mellett a természet iránti felelősség vállalása is hangsúlyt kap. „A szántók bérbe vannak adva, ha mondjuk, van egy bérlő, aki biogazdálkodást folytatna, akkor ő potenciális bérlőként mindenképpen előnyt élvezne" (Hunyady József).

\section{b, Fogyasztók}

A családnak a vállalkozás iránti elkötelezettségének következménye a fogyasztókkal való nagy fokú törődés (Leach, 2007). „A bor egy bizalmi termék... ha a mi termékünket valaki hazaviszi egy vasárnapi ebédhez, akkor tulajdonképpen közöttünk egy bizalmi kapcsolat kötődik. Hiszen, ha meghívjuk magunkhoz az anyósunkat, apósunkat meg a rokonságot, és átjönnek a vasárnapi ebédre, akkor mi kirakjuk azt a bort az asztalra, és nyilván nem szeretnénk lebőgni vele"Pécsinger János).

A megkérdezettek nagy része arra törekszik, hogy minél közvetlenebb kapcsolatba kerüljön az ügyfeleivel, mivel a személyes, közvetlen kapcsolat hűségesebb ügyfeleket eredményez.

Családi cégek esetében a fogyasztókkal való interakció általában személyesebb hangvételü, így az érzelmi reakciók is fontosak, amelyeket legtöbbször figyelembe is vesznek. Tapasztalatunk szerint a vevőkkel szembeni nagyobb rugalmasság és alkalmazkodóképesség jellemzi ezeket a cégeket. „Road show-kat és partikat szoktunk rendezni az üzleteknél, hogy a helyiek a sajátjuknak érezzék ezt a helyet, jöjjenek, szórakozzanak, kóstoljanak bort, hallgassanak zenét, hogy jobban megismerkedjünk egymással” (Pécsinger János).

Leach (2007) szerint az ilyen típusú cégek ügyfélközpontúbbak, ezért jobban odafigyelnek a termékeik és szolgáltatásuk minőségére. A minőséget egyenesen stratégiai célnak (Poza, 1995) tekintik. „Tehát nem mindegy, hogy egy ilyen terméket adunk oda egy kisgyermeknek, vagy pedig az agyonpermetezett szőlő levét” (Pécsinger János). A kiváló minőség jutalma és eredménye lehet gazdasági, a vevői lojalitás és a vállalkozás és/vagy család reputációjának növekedése is.

A család hírneve, imázsa is kiemelten fontos, hiszen a termék sokszor a család nevét viseli. „Nyilván azt szeretném, hogy rohadtul jó legyen, mert mi a nevünket tesszük ebbe a történetbe" (Pécsinger János).

c, Versenytársakkal, borászati közösséggel való együttmüködés

A versenytársakkal való együttműködés kiemelkedő példáit láthatjuk a hazai borászati szektorban. A különböző borvidékek együttmüködése valamilyen közös célért az összefogás legkülönbözőbb módjain valósul meg.

A Pannonhalmi borvidéken a PH-Érték az együttműködés eredménye. A Tokaji Közösségi Infrastruktúra (Tokaji Szőlő- és Bortermelési Közösségi Infrastruktúra Központ Nonprofit Kft.) A Tokaji Bormívelők Társasága az 1860-as években alakult meg, és a rendszerváltás után elevenítették fel újra. A Tokaji Borlovagrend szintén a helyi tradíciót folytatja, és a fő célja az, hogy megismertesse a világgal a tokaji bort, ezért ezek a borlovagrendek külföldi újságírókat és híres személyeket vesznek fel a soraikba borlovagként, akik majd a tokaji bor nagykövetei lesznek. A Tokaji Borbarátnők a helyi borásznők és birtok tulajdonosnők egyesülete, a tokaji bor népszerűsítésén kívül évente egy bizonyos összeget jótékonysági céllal iskoláknak adnak. A Tokaji Közösségi Infrastruktúra pedig egy közös palackot alkotott meg és védetett le. A Somló Superior a Somlói borvidék pincészeteinek összefogásából született meg: e védett eredetű somlói bort csak bioművelésből származó szőlőből lehet készíteni - ez teljesen egyedülálló Magyarországon.Szekszárd volt talán az első olyan borvidék, amely az elmúlt tíz évben megmutatta, hogyan kell együtt gondolkodni és közös projekteket megvalósítani, például elég csak megemlíteni a közös kóstolókat és a Szekszárd-palackot, amely a helyi fajtákat - kadarka, kékfrankos, bikavér - és termelőket hozza közös nevezőre. „egy borvidék imidzse, ha mi, termelők nem tartunk össze, akkor nem ér semmit." 


\section{(5) Természeti környezettel szembeni felelősség}

Az alapító személyes értékrendje alapvetően meghatározza a környezethez való viszonyt is, amely pedig felülírhatja a vállalkozás anyagi érdekeit is. „Nem vásároljuk meg a legjobb szántókat, hanem inkább kis gyepeket, amelyek talán nem annyira értékesek, de így védjük meg ezeket. Próbáljuk meghagyni, nem szántjuk fel, hanem természetes állapotukban tartjuk meg, csak kaszáljuk. Igen, az összes legelőt és rétet fenntartjuk, mert így sokkal természetesebb, mint egy szántó... És az erdőt is próbáljuk mindenképpen fenntartani természetes állapotában" (Hunyady József).

A természeti környezettel szembeni felelős magatartás kapcsán többször előkerült a biogazdálkodás kérdésköre. Hunyady gróf volt az első a környéken, aki bevezette a környezetkímélő termelési technológiát.

A környezeti terhelés kérdése a borosüvegek kapcsán is elökerült. Az egyik vizsgált családi vállalkozás a minőségi folyóbort csatos üvegben kínálja a fogyasztóinak. „Herótom van a mủanyagtól, bár sajnos nagyon sok fogyasztó választja azt, de igyekszünk őket arra szoktatni, hogy inkább a csatos, egyliteres üvegeket válasszák, hiszen gyönyörủek, és pontosan annyiért adjuk nekik oda, mint amennyiért mi vesszük... és adunk hozzá tároló fadobozt is, amelyben remekül lehet szállítani, és ki lehet tenni az asztalra....baromi jó terméket kapnak: ők is boldogok, én is boldog vagyok, és a környezetet sem terheljük a végén, mert tulajdonképpen a vásárlóink egy újracsomagolt terméket visznek haza" (Pécsinger János).

A környezeti felelősségvállalással és környezetterheléssel kapcsolatos kérdésekre adott válaszokban nagy hangsúlyt kapott az innovációhoz való viszony is. Mindegyik vállalkozásnál megfigyelhető volt az innovációs képesség és az innovációra való hajlandóság, amely magára a termékre, a különböző folyamatokra is vonatkozik, de ebbe a körbe tartozik az új technológiák bevezetésére való nyitottság is. „a meteorológiai előrejelzés: akkor permetezzünk, amikor kell. És ha már egyet meg tudunk spórolni, az is remek, amikor régen nyolcszor permeteztünk, de most öcsém már öt-hat védekezéssel megoldja. Azért ez is a környezeti ártalom csökkentése. És ehhez megint mi kell? Pénz, hogy legyen egy mérőállomás, amely megméri nekem a páratartalmat, és különböző programok segítségével megmondja, hogy mikor érdemes permetezni; holnapután, vagy elég csak három nap múlva" (Takler András).

\section{(6) Filantróp felelősség}

A filantróp magatartás az önként vállalt, az életminőség javítását célzó, belső motivációból fakadó felelős viselkedést jelenti. Általában a vezető és/vagy tulajdonos család, de sok esetben egy alkalmazott számára fontos ügy vagy intézmény kerül támogatásra; idetartoznak a tulajdonos által kedvelt sportcsapatok vagy -klubok, jótékonysági szervezetek támogatása, jótékonysági borárveréseken való részvétel vagy a helyi iskolák, közösségek részére adott kisebb-nagyobb támogatások, tárgyi adományok vagy nyújtott szolgáltatások.

„Mi a kosárcsapatot támogatjuk: nemzetközi meccsek rendezésekor a bírókat ingyen és bérmentve helyezzük el itt a házban. Emellett rengeteg bortámogatást adunk; ha a város vagy a szőlőnk közelében fekvő általános iskola szokott például farsangi bálra tombolaajándékot kérni tőlünk. De a helyi gyakorlóiskolának vagy alapítványoknak is gyakran adományozunk. Ezek bár apróságok, de sok kicsi sokra megy" (Takler András).

A környezeti felelősségvállalás formális módon tetten érhető egy ilyen jellegű alapítványban végzett aktív munkában is. Például a Hunyady gróf által létrehozott Zöld Folyosó Alapítvány a Balatontól a Dráváig húzódó területek védelmét szolgálja. „Szerintem mindenkinek meg kell találnia a saját jó ügyét, amelyet támogatni szeretne, és annak nem kell feltétlenül olyan ügynek lennie, amelyet az emberek elvárnának tőle...nyilván hatással volt rám, hogy a nagyapám mit tartott fontosnak. A hosszú távon való gondolkodás meg a birtokhoz, földhöz, vidékhez való kötődés közös bennünk. Viszont különbség, hogy ő sokkal többet áldozott szociális ügyek támogatására. Én is inkább a természetvédelem felé húzok, míg a nagyapám inkább iskolákat, zárdákat és kórházakat támogatott" (Hunyady József).

\section{A társadalmi és környezeti felelösségvállalás motivációi}

A társadalmi és környezeti felelősségvállaláshoz kapcsolódó motivációk azonosítása különösen fontos, mert következményeik által alakulnak ki azok a cselekvések, amelyek a célok eléréséhez szükségesek. Számos tanulmány készült a különböző iparágak fenntarthatóságával kapcsolatban, így a borászat vonatkozásában is (Silverman et al., 2005), illetve azzal, hogy milyen motivációk húzódhatnak meg a kis- és középvállalkozások környezeti 
felelősségvállalása mögött. Ezek alapján azok lehetnek önkéntes, a piac vagy a kormány, illetve a vevők, fogyasztók által ösztönzött motivációk is.

Az önkéntes motivációk közé sorolhatók a családi vállalkozás szocioemocionális vagyonának megtartásához kötődő motivációk, amelyek lehetnek belsők (például a generációváltás szándéka vagy a család jó hírnevének megőrzése) vagy kívülről jövők (például szociális kötelékek vagy a helyi közösség); ezek ösztönözhetik a vezetőket az erre irányuló döntések meghozatalára.

A hosszú távú orientáció a mezőgazdasági vállalkozások esetén különösen fontos. A gazdálkodással kapcsolatos speciális ismeretek és gyakorlatok nagyobb ösztönző erővel bírnak a generációk közötti átadásra. A családi vállalkozások általában nagyobb figyelmet fordítanak a víz és a talaj megőrzésére, valamint a hatékony energiafelhasználásra, mint a nem családi mezőgazdasági vállalkozások (Tweeten, 1987; James, 1999). „Ha valaki szintén szeretné ezt így, ebben a formában továbbadni a gyerekeinek, unokáinak, akkor ezen azért el kell gondolkodnia. Hiszen, ha agyonműtrágyázza a talajt, mert a műtrágyát egy só, akkor az unokája mit fog azon a földön majd még termelni? Az, aki így, hosszú távon gondolkodik, nem teszi tönkre a saját utódjainak jövőjét" (Wille-Baumkauff Márta).

A szocioemocionális vagyon másik fontos eleme a család jó hírneve, amely szintén sarkallhatja a családot a környezetvédelmi szempontok szem előtt tartására, bár ilyen megfontolásokat a bemutatott családi vállalkozások esetében nem tapasztaltunk.

A belső motivációk köréhez tartozik a bioborászat egy még szigorúbb előírásokat követő ága, a biodinamikus borászat elvei szerinti gazdálkodás, amely az alapító család értékrendjével összhangban a 19. századi osztrák filozófus, Rudolf Steiner ideológiáján alapszik, aki a szőlőtermesztést egy állandó körforgásban működő rendszernek tekintette.

A biogazdálkodás kapcsán a környezet védelme mellett azonban meg kell említeni a borászatok által okozott egyéb környezetterhelés okozta problémákat. Mindenhol azt tapasztaltuk, hogy a gazdasági megfontolások mellett különösen fontos a hatékony és a minél természetbarátabb művelési mód megtalálása a csatornákra, a hulladékgazdálkodásra, a permetezésre és a használt gépekre tekintettel, ami egyszerűen a természet szeretetéből, tiszteletéből, e belső motivációból ered.

A bioműveléssel kapcsolatban egy másik magyarázat is felmerült a beszélgetések során, nevezetesen az európai uniós támogatási rendszer. „Tehát olyan rengetegen nem vagyunk még, de fejlődik az ügy. Azt hiszem, hogy a biovonal egyre erősödik, mert arra ugye van EU-s támogatás. Tehát aki vállalja, hogy biogazdálkodást folytat, akkor az területalapú támogatásként több pénzt kap, mint ha hagyományos módon művelné a földet. Ráadásul a kormányzat is indított 2016-ban egy hasonló programot...mert addig százezer hektár volt ökológiai Magyarországon, és most körülbelül háromszázezer, tehát sokat segített" (Wille-Baumkauff Márta).

A Magyarországon egyedülálló hegyközségi rendszer nagyon szigorú feltételeket támaszt a borok készítésével kapcsolatban, valamint a borokhoz használható adalékanyagokat a magyar bortörvény szabályozza. Az Országos Borminősítő Intézet ellenőrzi a szigorú előírások termelők általi betartását. „Heti szinten vannak ellenőrzések, jön a NAV, a szőlőszaporítóés növényegészségügy-felügyelet. Emiatt külön kell foglalkoztatnunk egy talajvédelmi szakértőt, egy növényvédelmi szakértőt, egy AKG-s [agrár-környezetgazdálkodási] szaktanácsadót és egy vízügyi szakmérnököt” (Ungerbauer Anikó).

A belső motiváció és a törvényi előírások mellett még fontos szempont a környezeti felelősségvállalásból származó versenyelőny is. A megkérdezett vállalkozók közül többen arról számoltak be, hogy például Ausztriában sok borászat rájött, megkülönböztethetik magukat azzal, ha biogazdálkodást folytatnak, amely versenyelőnyt jelenthet számukra, hiszen termékeiket drágábban tudják értékesíteni.

A válaszadók kiemelték, hogy tapasztalatuk szerint hazánkban még a környezetvédelmi szempontok, az ökologikus gazdálkodás sem motiválja a vásárlói döntést. „A magyar fogyasztók legnagyobb részét nem [érdekli]. Ennek mondjuk az is az oka, hogy a bioboroknak talán még nincs külön kialakított imidzsük, nincs jó marketingjük, vagy esetleg a biotermékeket még nem kimondottan keresik a vásárlók" (Wille-Baumkauff Márta). 


\section{Eredmények}

Kutatási kérdéseink közül az első a családi vállalkozások nem gazdasági céljaihoz tartozó társadalmi és környezeti felelősségvállalással kapcsolatos céljaira vonatkozott, mind a vállalkozási, mind a családi szempontokat alapul véve (lásd: 2. táblázat).

2. táblázat: A családi vállalkozások társadalmi és környezeti felelősségvállalásának céljai. Forrás: saját munka

\begin{tabular}{|c|c|}
\hline Vállakozási célok & Családi célok \\
\hline $\begin{array}{c}\text { Környezeti fenntarthatósági szempontok } \\
\text { érvényesítése }\end{array}$ & Családi harmónia fenntartása \\
\hline Termék- és szolgáltatásfejlesztés & Családi örökség értékének fenntartása \\
\hline \multirow[t]{7}{*}{$\begin{array}{l}\text { Természet védelméhez kapcsolódó inno- } \\
\text { váció }\end{array}$} & Közösségben kialakított kép és hírnév \\
\hline & $\begin{array}{l}\text { Alkalmazottakhoz, vállalati kultúrához kap- } \\
\text { csolódó célok }\end{array}$ \\
\hline & Fogyasztók igényinek való megfelelés célja \\
\hline & Helyi közösség iránti elköteleződés \\
\hline & Versenytársakkal való együttműködés \\
\hline & Társadalom felé való elkötelezettség \\
\hline & Filantrópia \\
\hline
\end{tabular}

A vállalkozás nem gazdasági jellegű céljai tervezettek, tudatos célokként fogalmazódnak meg; idetartozik a természet terhelésének kérdése, a természet védelme vagy az ezzel összefüggő innováció, termék- és szolgáltatásfejlesztés. Egyre fontosabbá válik az olyan típusú tudományos megoldások alkalmazása, amelyek támogatják a környezeti felelősségvállalás gyakorlatainak megvalósulását.

A család által megfogalmazott, tudatos, nem gazdasági jellegü CSR-célokat nem fedeztünk fel. A közösségben kialakított kép és hírnév, az alkalmazottakkal, a fogyasztókkal, a helyi közösséggel vagy akár a versenytársakkal kapcsolatos CSR-tevékenységek nem tudatos célkitüzésekként, intézményesítve vagy misszióként öltenek formát a vizsgált vállalkozásokban.

3. táblázat: A családi vállalkozások társadalmi és környezeti felelősségvállalásának motivációi. Forrás: saját munka

\begin{tabular}{l|l}
\hline Ösztönös motivációk & $\begin{array}{l}\text { szocioemocionális vagyonának megtartásához kö- } \\
\text { tődő motivációk } \\
\text { hosszú távú orientáció } \\
\text { család jó hírneve } \\
\text { belső motiváció pl. hitrendszer }\end{array}$ \\
\hline Szabályozások által ösztönzött & $\begin{array}{l}\text { európai uniós támogatási rendszer } \\
\text { törvényi előírások }\end{array}$ \\
\hline Fogyasztók által ösztönzött & versenyelőnyt jelenthet \\
\hline
\end{tabular}

A második kutatási kérdés a családi vállalkozások társadalmi és környezeti felelősségvállalással kapcsolatos motivációira vonatkozott. A társadalmi és környezeti felelősségvállalás motivációkkal kapcsolatban három csoportot különítettünk el. Az (1) első a nem tudatos, 
vagyis ösztönös motivációk, a (2) második a különböző szabályozások miatt bevezetett CSRtevékenységek, míg a (3) harmadik csoportba a fogyasztók vagy a piaci verseny által ösztönzött ilyen jellegü tevékenységek tartoznak (lásd: 3. táblázat).

\section{(1) Ösztönös motivációk}

A motivációk első dimenziója a belső késztetésből fakadó, ösztönös motivációk csoportja. Az ösztönös motivációk alapját az alapító érték- és hitrendszere, kulturális hovatartozása képezi, amely áthatja a családi vállalkozás teljes működését, beleértve a CSR-tevékenységeket is; idetartozik a vezető cég iránti személyes elkötelezettsége és az innovációra való nyitottsága. Válaszadóink egyetértettek abban, hogy CSR-gyakorlataikat nem anyagi megfontolásból folytatják.

Szintén az ösztönös kategóriába tartozik a család szocioemocionális vagyonának megőrzésére irányuló vágya, amely magában foglalja a jó hírnév fenntartásának fontosságát és a generációváltás szándékát. A család hosszú távú orientációja a családi vállalkozás sikerességének egyik feltétele.

4. táblázat: A családi vállalkozások társadalmi és környezeti felelősségvállalásához kapcsolódó motivációk jellegzetességei. Forrás: saját munka

\section{Belsõ érintettek csoportja}

Család felé

Alkalmazottak felé

\section{Külső érintettek csoportja}

Helyi közösség

Fogyasztók

Beszállítók

Versenytársak

Természeti környezet
Jellemző

Motiváció

\begin{tabular}{l|l}
\hline $\begin{array}{l}\text { kiszámíthatóság } \\
\text { vezető személyének megbízhatósága, személyes } \\
\text { imázs } \\
\text { vállalkozás gazdasági túléléséhez kötődő felelősség }\end{array}$ & $\begin{array}{l}\text { család megélhetésének biztosí- } \\
\text { tása }\end{array}$ \\
\hline $\begin{array}{l}\text { munkavállalók anyagi megbecsülése } \\
\text { anyagi felelösség } \\
\text { méltányosság } \\
\text { munkahelyi biztonság }\end{array}$ & $\begin{array}{l}\text { jó szervezeti kultúra kialakitása } \\
\text { alacsonyabb fluktuáció }\end{array}$ \\
\hline $\begin{array}{l}\text { kiemelkedő jelentőségú } \\
\text { pontos kifizetések } \\
\text { elköteleződés a helyi természeti környezet felé } \\
\text { a helyi közösség támogatása }\end{array}$ & kat \\
\hline $\begin{array}{l}\text { termékfelelősség } \\
\text { figyelembe veszik a vásárlók igényeit, elvárásait és re- } \\
\text { akcióit, ügyfélközpontúság } \\
\text { közvetlen kapcsolatra való törekvés }\end{array}$ & valós szükségletek kiszolgálása \\
\hline $\begin{array}{l}\text { pontos fizetés } \\
\text { ritkán cserélődnek }\end{array}$ & hüséges ügyfelek \\
\hline $\begin{array}{l}\text { együttmüködés fontos } \\
\text { versenyszellem }\end{array}$ & család jóhírének növelése \\
\hline $\begin{array}{l}\text { figyelembe veszi a természet torráso- } \\
\text { környezetvédelmi szempontok szem előtt tartására }\end{array}$ & személyes, bizalmi kapcsolatok \\
\hline
\end{tabular}

(2) Szabályozások által ösztönzött CSR

A motivációk második csoportja a törvényi szabályozásoknak való megfelelés kényszere, amely elsősorban a környezeti felelősséggel kapcsolatban volt megfigyelhető; idetartozik a hazai borászatok számára kötelezően előirt, szigorú szabályok betartása, a biotermelésre 
való átállás lehetőségének megfontolása, az EU-s források lehívásához kapcsolódó feltételek teljesítése, de az önkéntesen választott (lásd biodinamikus borászatban használt Demeter tanúsítvány) rendszereknek való megfelelés is.

(3) Fogyasztók által ösztönzött CSR

A harmadik csoport a fogyasztói igények kielégítésének és a versenyelőnyhöz való jutás vágya. llyen stratégiai megfontolásokkal a vizsgált cégekben nem találkoztunk.

A társadalmi és környezeti felelősségvállalással kapcsolatban azonosított motivációk jellegzetességei a következő táblázatban kerültek összefoglalásra (lásd: 4. táblázat).

A harmadik kutatási kérdéssel azt szerettük volna megtudni, hogy a társadalmi felelősségvállalás hogyan épül be a vállalkozás egyes működési területeibe.

Kutatásunk alátámasztja a Spence (2014) által leírt piramis felépítését; ez alapján a kiindulási pont a személyes integritás biztosításának felelőssége, közvetlenül erre épül rá a családdal szembeni gazdasági felelősség, a vállalkozás túlélése biztositásának felelőssége. Az első dimenzió harmadik eleme az etikai felelősség, amely kimondva-kimondatlanul minden általunk vizsgált vállalkozás összes megismert tevékenységét áthatja. Kutatási eredményeink azt mutatják, hogy a menedzsment felelőssége gazdasági, jogi és etikai felelősségvállalásban nyilvánul meg. A piramis legtetején a filantróp felelősség áll, amellyel a családi dimenzióban nem találkoztunk.

A belső érintettek második csoportja az alkalmazottak felé történő felelősségvállalás. Ennek megvalósulása hosszú távú, kölcsönös bizalmon alapuló kapcsolatban mutatkozik meg, illetve abban, hogy a dolgozókkal tisztelettel és méltósággal bánnak. A munkavállalók részére az alkalmazandó törvényekkel összhangban megkötött munkaszerződések biztonságos munkakörülményeket teremtenek, a rendszeresen adott pluszjuttatások, a munkavállalók részére biztosított képzések és a méltányos munkakörülmények szintén a vizsgált vállalatok CSR-tevékenységeinek részét képezik.

A külső érintettekre tekintettel fontos a beszállítókkal és az ügyfelekkel való együttmüködés. A beszállítók kapcsán megállapítható, hogy a jól bevált régi beszállítókat a vállalkozások ritkán cserélik le, valamint a hasonlóan környezetorientált érintettekkel való együttmüködés preferálása is megfigyelhető.

A fogyasztókkal való kiemelt törődés, a személyes kapcsolatok kialakítása fontos szerepet játszik a vizsgált vállalkozások CSR-tevékenységeiben, az stratégiai célként is megjelenik, ez pedig minőségi termékek és szolgáltatások nyújtását követeli meg.

Megfigyelhettük, hogy fontos a helyi közösséggel való együttmüködés, ez a fajta elköteleződés leginkább a helyi munkaerő alkalmazását és a helyi közösség támogatását jelenti.

A versenytársakkal való együttműködés a borvidék jó hírnevének öregbítése céljából közös termékek megalkotásában és szövetségek megalapításában ölthet testet.

A természeti környezettel szembeni felelős viselkedés beépül a mindennapi müködésbe; idetartozik a tanúsítványok megszerzése, valamint a környezetbarát, technológiai és természetvédelmi újitások bevezetése.

A negyedik kutatási kérdésünk az volt, hogy a CSR-gyakorlatok milyen módon befolyásolják az érintettekkel kialakított viszonyt. A megkérdezett vállalkozók arról számoltak be, hogy az alkalmazottakkal kialakitott személyes kapcsolat és a velük szembeni gondoskodó magatartás, beleértve például a jó munkakörnyezet kialakitását vagy a diverzitás megfelelő kezelését, a fluktuáció csökkenéséhez vezet.

A beszállitókkal kialakított szorosabb, bizalmi kapcsolat megbízhatóbb ellátási láncot eredményez, míg a helyi környezet ismerete előnyt jelent a humán erőforrás jobb kihasználásában. A versenytársakkal kapcsolatban elmondható, hogy a vizsgált vállalatokra a versengés helyett inkább az együttműködés jellemző.

A filantropikus tevékenységek leginkább a helyi közösség érdekében önként vállalt anyagi segítségben testesülnek meg, és nem hoznak nagy változást a vállalkozások életébe.

A Lambrecht és Uhlaner (2005) által megfogalmazott felelős tulajdonlás a család, a vállalkozás és a közösség iránti hosszú távú elköteleződést jelenti. Eredményeink alapján kijelenthetjük, hogy a vizsgált vállalkozásoknak sikerült egyensúlyba hozni egymással a két oldalt, és így pozitív példával szolgálhatnak a felelős családi tulajdonlásra és a társadalmi felelősségvállalásra.

Empirikus kutatásunk azt támasztja alá, hogy a gazdaságos és nyereséges müködés mellett kiemelkedően fontos szerep jut a társadalmi és környezeti felelősségvállalásnak. A megvizsgált és bemutatott családi vállalkozásoknál belső motivációból fakadó CSR- 
tevékenységeket figyelhettünk meg, és ezek a cégek összhangba tudták hozni a CSR három pillérét, a „fenntartható, nyereséges és etikus” működésre vonatkozó elvárásokat.

\section{6. Összegzés}

A családi vállalkozások változatos CSR-tevékenységeinek alapját a családon belüli szorosabb kapcsolatok, a közös történet, a hosszú távon történő együtt gondolkodás és a szocioemocionális vagyon képezi. A kutatás bebizonyította, hogy a vállalkozáshoz kötődő erős érzelmi szálak tovább erősítik a hosszú távú orientációt, az elköteleződést.

A család nem gazdasági jellegủ céljai, a szocioemocionális vagyon megtartása és az ezzel összefüggő hosszútávú orientáció, a család hírnevéhez kapcsolódó negatív konnotációk elkerülésének szándéka, az alkalmazottakkal való személyes kapcsolat és a környezet védelme mind-mind meghatározza a családi vállalkozások CSR-tevékenységeit. A környezeti fenntarthatóság kérdésköre vonatkozásában ugyanakkor megállapítható, hogy a belső motiváció megléte ellenére jellemzőek a törvényi kötelezettség miatt végzett CSR-tevékenységek is.

Sharma (2004) szerint a vállalkozáskutatás végső célja, a családi vállalkozások működésének javitása. A CSR piramis egy dinamikusan adoptálható keretnek tekinthető, amely mind a jelenre, mind a jövőre is fókuszál (Caroll, 2016). A piramis különböző szervezeti környezetben is alkalmazható és a gyakorlatban is segítséget nyújthat a hazai családi vállalkozásoknak, hogy holisztikusan és tudatosan gondolkodjanak a CSR-hoz kapcsolódó tevekénységeikről.

A borászatok kiemelkedő szerepet játszanak a vidéki környezet fenntarthatóságában, így a kutatásunkkal azonosított célok, motivációk bővítik a hazai családi vállalkozásokról szóló tudásanyagot. Az összegyuujtött fenntarthatósági kezdeményezésekhez kapcsolódó motivációkat ismerete szükséges mind a menedzsment, mint a környezetvédelem szempontjából, hiszen a belső tényezők erőteljesen befolyásolják a társadalmi és környezeti fenntarthatóság előmozdítását, különösen családi vállalkozások esetében.

A kutatásunkban vizsgált vállalkozások kis száma miatt a leírt megfigyelések nem általánosíthatók. Nem derült például ki, hogy azok a családi vállalkozások, melyek esetében már nem az első generációs családtag ül a döntéshozatali pozícióban, fogékonyabbak-e valamely CSR-tevékenységre.

Tanulmányunk feltáró jellegű, és mint ilyen nem határozza meg a különböző érintett csoportokkal szembeni társadalmi felelősségvállalás mértékét. A jelenlegi kutatás folytatásaként szükség lenne a CSR-tevékenységek jellegének mélyebb megismerésére. A családi vállalkozások heterogenitásából adódóan eltérő jellegű CSR-tevékenységek figyelhetők meg az egyes vállalkozások esetében. A kutatásunkban vizsgált vállalkozások kis száma miatt a leírt megfigyelések nem általánosíthatók, illetve a családi vállalkozások generációs jellemzőiből fakadó fenntarthatósági gyakorlattal kapcsolatos eltérések nem képezték a vizsgálat tárgyát.

A családi vállalkozások vizsgálata nemcsak a családi tulajdonban lévő cégek számára lehet fontos és hasznos, hanem például azért is, mert sokuk olyan gyakorlatokat folytat, amely a nem családi cégek számára is példa lehet. Ilyen például a családi vállalkozás alkalmazottainak a vállalkozás iránti lojalitása, és érdekes kérdés, hogy hogyan hat ez a hűség a családi vállalkozásra. Ez a hűséges alkalmazottakat kereső nem családi vállalkozások számára is kritikus fontosságú lehet.

Végezetül tanulmányunk célja, hogy felhívjuk a figyelmet a magyar családi vállalkozások felelős viselkedésének fontosságára, amelyek esetében tulajdonosi és/vagy családi döntés a CSR mindennapi működésbe integrálása. A gazdasági javak előteremtése és a család életminőségének javítása mellett a természettudatosság és a társadalmi érzékenység értékei is fontos szerepet kapnak.

Finanszírozás / Funding: A kutatási projektet az Innovációs és Technológiai Minisztérium Tématerületi Kiválósági Programja és a Budapesti Gazdasági Egyetem között létrejött együttműködési megállapodás (TKP2020-IKA-01) támogatja. / This research was supported by a grant from the Thematic Excellence Programme of the Hungarian Ministry for Innovation and Technology to the Budapest Business School (TKP2020-IKA-01). 


\section{Források}

1. Alonso, A.D. (2010). How 'green' are small wineries? Western Australia's case. British Food Journal, Vol. 112 No. 2, pp. 155-170. DOI:10.1108/IJWBR-2012-0015

2. Aminoff, P., Blom, A., Pärssinen, K., Helkama, J., Koiranen, M., Nyman, K. \& Paasikivi, K. (2004). On the characteristics and duties involved in responsible ownership. Helsinki, Family Business Network, Finland.

3. Aragón-Correa, J. A. \& S. Sharma (2003). A contingent resource-based view of proactive corporate environmental strategy. Academy of Management Review, 28: 71-88. DOI:10.2307/30040690

4. Astrachan, J. H. (1988). Family Firm and Community Culture. Family Business Review, 1(2): 165-189. https://doi.org/10.1111/j.1741-6248.1988.00165.x

5. Babbie, E. (2017). A társadalomtudományi kutatás gyakorlata; 9. Kiadás 6. Magyar nyelvű fordítása; Balassi Kiadó, Budapest.

6. Bank Dénes (2017): Implicit és explicit, valamint belső és külső CSR egy kettős függésben lévő piacgazdaságban különös tekintettel a munkavállalókról való gondoskodásra. Doktori értékezés, Budapest. Kézirat

7. Basco, R. (2017). Where do you want to take your family firm? A theoretical and empirical exploratory study of family business goals. Business Research Quarterly. ACEDE, 20(1), 28-44. https://doi.org/10.1016/j.brq.2016.07.001

8. Berrone, P., Cruz, C., Gómez-Mejía, L. \& Larraza-Kintana, M. (2010). Socioemotional wealth and corporate responses to institutional pressures: Do family-controlled firms pollute less? Administrative Science Quarterly, 55, 82-113.

9. Berrone, P., Cruz, C. \& Gomez-Mejia, L. R. (2012). Socioemotional wealth in family firms: Theoretical dimensions, assessment approaches, and agenda for future research. Family Business Review, 25, 258-279. DOI:10.2189/asqu.2010.55.1.82

10. Besser, T. L. (1998). The significance of community to business social responsibility. Rural Sociology, 63(3), 412-431. https://doi.org/10.1111/j.1549-0831.1998.tb00686.x

11. Bingham, J.B., Dyer, W.G., Jr. Smith, I. \& Adams, G.L. (2011). A stakeholder identity orientation approach to corporate social performance in family firms. Journal of Business Ethics, 99(4), 565-585. DOI: 10.1007/s10551-010-0669-9

12. Carroll, A. B. (1979). A Three-Dimensional Conceptual Model of Corporate Performance. Academy of Management Review, 4(4) pp. 497-505. https://doi.org/10.2307/257850

13. Carroll, A.B. (2016). Carroll's pyramid of CSR: taking another look. International Journal of Corporate Social Responsibility 1,3 (2016). https://doi.org/10.1186/s40991-016-0004-6

14. Cennamo, C., Berrone, P., Cruz, C. \& Gómez-Mejía, L.R. (2012). Socioemotional wealth and proactive stakeholder engagement: Why family controlled firms care more about their stakeholders. Entrepreneurship Theory \& Practice, 36(6), 1153-1173. https://doi.org/10.1111/j.1540-6520.2012.00543.x

15. Chrisman, J. J., Chua, J. H., Kellermanns, F. \& Chang, E. (2007). Are family managers agents or stewards? An exploratory study in privately held family firms. Journalof Business Research, 60, 1030-1038. DOI:10.1016/j.jbusres.2006.12.011

16. Craig, J.B., Dibrell, C. \& Davis, P.S. (2008). Leveraging family-based brand identity to enhance firm competitiveness and performance in family businesses. Journal of Small Business Management, 46(3), 351-71. DOI:10.1111/j.1540-627X.2008.00248.x

17. Davis, J. H., Schoorman, F. D. \& Donaldson, L. (1997). Toward a stewardship theory of management. Academy of Management Review, 22(1), 20-47. https://doi.org/10.2307/259223

18. Denzin, N. K. \& Lincoln, Y. S. (2011). The SAGE Handbook of Qualitative Research. Thousand Oaks, USA: SAGE

19. Dyer, W.G. Jr \& Whetten, D.A. (2006). Family firms and social responsibility: preliminary evidence from the S\&P 500. Entrepreneurship: Theory and Practice, Vol. 30 No. 6, pp. 785-802. https://doi.org/10.1111/j.1540-6520.2006.00151.x

20. Etzioni, A. (1993). The Spirit of Community: The Reinvention of American Society, Simon and Schuster, New York, NY.

21. Etzioni, A. (1996). The responsive community: a communitarian perspective. American Sociological Review, Vol. 61, pp. 1-11. https://doi.org/10.2307/2096403

22. Fernando, M. \& Almeida, S. (2012). The organizational virtuousness of strategic corporate social responsibility: a case study of the Sri Lankan family-owned enterprise MAS Holdings. European Management Journal, Vol. 30 No. 6, pp. $564-576$. DOI:10.1016/j.emj.2012.08.003

23. Freeman E. R. (1994). The Politics of Stakeholder Theory: Some Future Directions. Business Ethics Quarterly, Published by: Philosophy Documentation Center 4(4), 409-421. 10.2307/3857340

24. Gómez-Mejia, L. R., Cruz, C., Berrone, P. \& De Castro, J. (2011). The bind that ties: Socioemotional wealth preservation in family firms. The Academy of Management Annals, 5(1), pp. 653-707. DOl:10.1080/19416520.2011.593320

25. Gómez-Mejia, L.R., Haynes, K.T., Núñez-Nickel, M., Jacobson, K.J. \& Moyano-Fuentes, J. (2007). Socioemotional wealth and business risks in family-controlled firms: evidence from Spanish olive oil mills. Administrative Science Quarterly, Vol. 52 No. 1, pp. 106137. https://doi.org/10.2189/asqu.52.1.10

26. Habbershon, T. G. \& Williams, M. L. (1999). A resource-based framework for assessing the strategic advantages of family firms. Family Business Review, 12(1), pp. 1-25. https://doi.org/10.1111/j.1741-6248.1999.00001.x

27. Hirigoyen, G. \& Poulain-Rehm, T. (2014). The Corporate Social Responsibility of Family Businesses: An International Approach. International Journal of Financial Studies, 2014, 2, 240-265. doi:10.3390/ijfs2030240

28. Hofstede, G. (2011). Dimensionalizing Cultures: The Hofstede Model in Context. Online Readings in Psychology and Culture, 2(1), 1-26. https://doi.org/10.9707/2307-0919.1014

29. Kása, R., Radácsi, L. \& Csákné Filep, J. (2019). Családi vállalkozások definíciós operacionalizálása és hazai arányuk becslése a kkvszektoron belül. Statisztikai Szemle, 97(2),146-174. DOI: https://doi.org/10.20311/stat2019.2.hu0146

30. Kellermanns, F. W. \& Eddleston, K. A. (2007). A family perspective on when conflict benefits family firm performance. Journal of Business Research, 60, 1048-1057. https://doi.org/10.1016/j.jbusres.2006.12.018

31. Lambrecht, J. \& Uhlaner, L.M. (2005). Responsible Ownership of the Family Business. State-of-the-Art. FBN-IFERA World Academic Research Forum, EHSAL Brussels, September

32. Leach, P. (2007): Family Businesses the Essentials. London: Profile Books

33. Maher, M. \& Andersson, T. (2002). Corporate governance: effects on firm performance and economic growth. In McCahery, J., Moerland, P., Raaijmakers, T. and Renneboog, L. (Eds.), Corporate Governance Regimes. 386-418. Oxford. 
34. Morck, R., \& B.Yeung (2004). Family control and the rent seeking society. Entrepreneurship Theory and Practice, 28, $391-409$. DOI:10.1111/j.1540-6520.2004.00053.x

35. O'Boyle, E. H., Jr. Rutherford, M. W. \& Pollack, J. M. (2010). Examining the relation between ethical focus and financial performance in family firms: An exploratory study. Family Business Review, 20, 1-17. https://doi.org/10.1177/0894486510375412

36. Poza, E. J. (1995). Global competition and the family-owned business in Latin America. Family Business Review, 8 (4), $301-311$. https://doi.org/10.1111/j.1741-6248.1995.00301.x

37. Sharma, P. (2004). An overview of the field of family business studies: current status and directions for the future. Family Business Review, 17(1), 1-36. https://doi.org/10.1111/j.1741-6248.2004.00001.x

38. Sharma, P., Chrisman, J.J. \& Chua, J.H. (1996). A Review and Annotated Bibliography of Family Business Studies; Kluwer Academic Publishers: Assinippi Park, MA, USA.

39. Silverman, M. \& Lanphar, T. (2003). Benziger family winery. Paper presented at Greening of Industry Network Conference October, San Francisco, CA.

40. Silverman, M., Marshall, R.S. \& Cordano, M. (2005). The greening of the California wine industry: implications for regulators and industry associations. Journal of Wine Research,Vol. 16 No. 2, pp. 151-169. https://doi.org/10.1080/09571260500331574

41. Spence, J. L. (2014). Small business social responsibility: Expanding core CSR theory, Business \& Society. (4), 1-33. https://doi.org/10.1177/0007650314523256

42. Szlávik, J. (2009). A vállalatok társadalmi felelősségvállalása. Complex Kiadó Kft., Budapest.

43. Tweeten, L. (1987). Has the Family Farm Been Treated Unjustly? in G. Comstock, ed., Is There a Moral Obligation to Save the Family Farm? Ames, IA: lowa State University Press, pp. 212 - 32.

44. Uhlaner, L. M., Van Goor-Balk, H. J. M. \& Masurel, E. (2004). Family businessand corporate social responsibility in a sample of Dutch firms. Journal of Small Business and Enterprise Development, 11(2), 186-194. https://doi.org/10.1108/14626000410537128

45. Zellweger, T. M., Kellermanns, F. W., Chrisman, J. \& Chua, J. (2011). Family control and family firm valuation by fam- ily CEOs: The importance of intentions for transgenerational control. Organization Science, 1, 1-36. DOI:10.1287/orsc.1110.0665

46. Zellweger, T. - Astrachan, J. (2008). On the emotional value of owning a firm. Family Business Review, 4(4), 347-363. 